\title{
KEMANDIRIAN DAN ATENSI SISWA YANG DIAJAR MENGGUNAKAN GROUP INVESTIGATION TERINTEGRASI POWER TEACHING DALAM MATA PELAJARAN BIOLOGI
}

\author{
Faridatul Maghfiroh ${ }^{1)}$ \\ Muslimin Ibrahim ${ }^{1)}$ \\ Soetjipto ${ }^{1)}$ \\ ${ }^{1)}$ Program Studi Pendidikan Sains, Pascasarjana Universitas Negeri Surabaya \\ e-mail:fas_kira@yahoo.com \\ telp. 085649593509
}

\begin{abstract}
Abstrak: Penelitian ini dilatarbelakangi oleh kenyataan bahwa masih terdapat indikator - indikator kemandirian dan atensi siswa yang rendah dalam proses pembelajaran. Penelitian ini bertujuan untuk mendeskripsikan tingkat kemandirian siswa (aspek percaya diri dan tanggung jawab), tingkat atensi siswa (aspek atensi berkelanjutan dan atensi eksekutif), hasil belajar kognitif, respon siswa, keterlaksanaan rencana pembelajaran, dan kendala-kendala pada proses pembelajaran. Desain penelitian yang digunakan adalah One Group Pretest-Postest Design, dan analisis data secara deskriptif kualitatif. Penelitian ini dilaksanakan pada siswa MA (Madrasah Aliyah) kelas X pada semester genap. Hasil penelitian menunjukkan tingkat kemandirian, tingkat atensi, dan tes hasil belajar siswa baik kelas putra ataupun kelas putri mengalami peningkatan. Respon siswa terkait pembelajaran menggunanakan Group Investigation terintegrasi Power Teaching juga mendapatkan respon yang baik, dan keterlaksanaan kegiatan pembelajaran tergolong pada kategori baik sekali. Kendala yang dihadapi hanya terkait pada pembuatan media presentasi, akan tetapi hal tersebut dapat diatasi dengan kreatifitas masing - masing siswa dalam pembuatan media tersebut. Simpulan penelitian ini, bahwa metode pembelajaran Group Investigation terintegrasi Power Teaching dapat mempertahankan kemandirian, atensi, dan hasil belajar kognitif siswa pada materi ekosistem. Metode tersebut juga mendapatkan respon yang baik, dan keterlaksanaan rencana pembelajaran yang juga tergolong baik sekali, serta kendala pembelajaran yang bisa diselesaikan dengan kreativitas siswa.
\end{abstract}

Kata Kunci: Biologi, Group Investigation terintegrasi Power Teaching, tingkat atensi siswa, tingkat kemandirian siswa.

Abstract: This research is based on the fact that the indicators of student's independence and attention are low in learning process. This research aimed to describe the level of student's independence (aspect of self confidence and responsibility), level of student's attention (sustained attention and executive attention), cognitive learning outcome, student's response, learning process, and the problems of learning process. The research design used is one group pretest-post test design, and analyzed using descriptive qualitative. The research was conducted on the students of senior high school (Madrasah Aliyah) class X in second semester. The result of research shows the level of student's independence, attention and test score of student learning outcome either male or female students were improving. The student's response of learning by using the integrated group investigation of power teaching also gets a good response and the learning process is categorized as very good category. Problem faced is only about creating the media of presentation but it can solved by student's creativity to create the media. The conclusion of this research, is that by using The Integrated group Investigation of power teaching can keep the student's independence, attention, and student learning outcome in ecosystem material. Thus method also gets a good response, and learning process is categorized as a very good category, and the problem of learning process can be solve by student's creativity.

Keywords: Biology, integrated group investigation of power teaching, level of student's attention, level of student's independence.

\section{PENDAHULUAN}

Kualitas akademik sangat dipengaruhi oleh beberapa faktor (Gani, 2008; Reber dalam Suwatik, 2010; Tu'u dalam Sunarsih, 2009), dua di antaranya adalah kemandirian (Gani, 2008) dan pemusatan perhatian (atensi) siswa saat proses belajar mengajar (PBM) berlangsung (Reber dalam Suwatik, 2010). Kedua faktor tersebut merupakan indikator dalam motivasi belajar siswa, hal ini sangat penting dalam proses pembelajaran, karena dengan motivasi yang tinggi akan mendorong siswa untuk melakukan tujuan tertentu yang ingin dicapainya (Uno, 2011), sedangkan saat ini, kemandirian dan atensi siswa di duga masih rendah. Kemandirian yang diduga masih rendah tersebut didukung oleh beberapa penelitian sebelumnya. Setiawan, dkk. (2013) menyatakan bahwa, sebagian siswa masih memiliki kemandirian yang rendah terutama dalam mengambil keputusan. Kurniawan (2012) juga menyatakan bahwa kemandirian siswa masih rendah terutama dalam hal membaca. Kurniawati (2010), kemandirian siswa masih tergolong rendah karena beberapa indikator yang ditemuinya, misalnya siswa cenderung pasif selama proses pembelajaran, siswa hanya mendengarkan, mencatat materi dan menghafalkannya.

Sementara itu, hasil pengamatan peneliti selama 3 bulan di SMA Katolik Frateran Surabaya (Januari-Maret 2013), siswa kelas $X$ di duga masih memiliki kemandirian yang rendah. Hal ini dibuktikan dengan beberapa indikator kemandirian yang rendah yang seringkali di jumpai pada siswa, yaitu siswa hanya mengandalkan hardcopy handout yang diberikan oleh guru (tidak adanya antusias siswa untuk mencari 
informasi secara mandiri), sebagian siswa seringkali terlambat dalam mengumpulkan tugas, siswa masih seringkali mencontek pada saat ujian berlangsung, dan jika guru tidak ada, siswa lebih memilih untuk melakukan aktivitas lain (bermain gitar ataupun menjadikan kelas tidak kondusif untuk belajar). Selain itu, indikator kemandirian yang rendah juga terlihat pada siswa kelas $\mathrm{X}$ MA Al-Ishlah Paciran, wawancara dengan guru biologi (20 Desember 2013) menyatakan bahwa selama dua tahun guru tersebut berada di pondok dan di sekolah bersama para siswa, siswa hanya bergantung pada informasi yang disampaikan oleh guru, siswa hanya menulis apa yang ditulis oleh guru di papan tulis (itupun dikarenakan diwajibkan menulis, ada pengumpulan buku catatan), dan siswa tidak aktif mencari informasi lain di buku ataupun internet.

Atensi siswa yang diduga masih rendah, juga dibuktikan oleh beberapa penelitian sebelumnya. Ekamayanti (2012) menyatakan bahwa atensi siswa masih rendah (siswa sering terlihat bercanda bersama teman-temannya, melamun, meminta izin untuk keluar ruangan, dan kurangnya rasa keingintahuan siswa terhadap proses pembelajaran). Riyanto (2012) juga menyatakan bahwa atensi dari separuh siswa yang diteliti masih tergolong dalam kategori sangat rendah dan rendah. Berdasarkan hasil pengamatan peneliti selama 3 bulan di SMA Katolik Frateran Surabaya (Januari-Maret 2013), siswa kelas $\mathrm{X}$ di duga masih memiliki atensi yang rendah. Hal ini karena masih terlihat indikator-indikator yang masih sering dilakukan oleh para siswa, yaitu siswa masih seringkali berbicara dengan temannya sehingga membuat kelas tidak kondusif untuk belajar, tidur di kelas, dan ijin keluar kelas pada saat PBM berlangsung, siswa juga mudah putus asa ketika diberi permainan untuk memasang-masangkan kartu (antara famili, genus, dan spesies). Indikator atensi yang rendah juga terlihat pada sekolah sasaran penelitian, MA Al-Ishlah. Hasil wawancara dengan guru biologi (20 Desember 2013) menyatakan bahwa masih terlihat sebagian siswa kelas X MA Al-Ishlah yang berbicara dengan temannya, sehingga menjadikan kelas kurang kondusif untuk belajar, dan beberapa masih ada yang tidur di kelas pada saat PBM berlangsung.

Berdasarkan penyebaran angket pada kelas X IPA (27 responden) dan X IPS (36 responden) MA Al-Ishlah Paciran, menunjukkan tingkat motivasi dan minat siswa terhadap mata pelajaran Biologi tergolong cukup baik. Hal tersebut dapat terjadi karena dua kemungkinan. Kemungkinan pertama, siswa tidak bersungguh-sungguh dalam menjawab, hal ini dibuktikan dengan adanya siswa yang berkata "menjawab ini tidak perlu waktu yang lama, cukup menjawab sekenanya". Peneliti juga pernah menjadi siswa di sekolah yang sama dengan para responden, kejadian menjawab angket secara asal juga sudah menjadi tradisi sejak periode peneliti. Kemungkinan yang kedua, pada dasarnya siswa memang memiliki motivasi dan minat yang tergolong cukup baik terhadap mata pelajaran biologi, namun cara mengajar guru yang menjadikan motivasi dan minat siswa terhadap mata pelajaran biologi menjadi turun. Hal ini dibuktikan dengan komentar yang disisipkan oleh beberapa siswa di lembar kosong pada angket yang disebarkan. Siswa menuliskan komentar di lembar kosong pada angket, yang mana diperoleh informasi bahwa siswa seringkali bosan dengan cara mengajar guru yang seringkali mencatat dan terkadang hanya membagikan hard copy handout tanpa menjelaskannya secara detail. Kegiatan mencatat dengan frekuensi yang tinggi, membuat siswa melakukan aktivitas lain, misalnya "tidur". Guru sangat jarang menggunakan media yang bisa menumbuhkan motivasi belajar siswa, misalnya dengan video. Menurut Syukur (2013) video sebagai media pembelajaran yang mengandung unsur audio visual dapat menampilkan gerak disertai dengan suara sehingga dapat menarik perhatian dalam membangun konsentrasi siswa. Siswa juga menyatakan bahwa guru seringkali mengajar terlalu serius (monoton, menulis dan menjelaskan) tanpa ada sisipan gurauan, sehingga hal tersebut membuat siswa mengantuk dan mudah jenuh dengan pelajaran yang disampaikan. Menurut Haryono (2007) bahwa faktor dominan yang menentukan motivasi belajar siswa adalah guru. Variasi guru dalam mengajar, seperti variasi penggunaan metode mengajar yang tidak monoton dan variasi dalam penggunaan alat peraga, merupakan beberapa contoh faktor guru yang bisa membangkitkan motivasi belajar siswa. Siswa juga menyebutkan bahwa pada dasarnya pelajaran biologi itu menyenangkan, akan tetapi penyampaian guru terkesan membosankan dan sangat jarang terdapat praktikum, sehingga siswa terpacu untuk melakukan aktivitas lain, misalnya mengobrol dengan temannya. Menurut Osborne \& Wittrock (dalam Maria, 2010) penyebab rendahnya minat dan perhatian (atensi) siswa dalam pembelajaran karena menganggap pelajaran sebagai sesuatu kejadian yang terisolir dari pengalaman hidup.

Faktor yang mempengaruhi kualitas akademik di atas dapat diperbaiki dengan melakukan pembenahan dalam PBM, misalnya variasi metode mengajar. Seperti yang dijelaskan di atas, menurut Haryono (2007) bahwa variasi guru dalam menggunakan metode mengajar dapat membangkitkan motivasi belajar siswa. Motivasi belajar siswa erat kaitannya dengan kemandirian siswa. Menurut Sunarsih (2009) bahwa kemandirian belajar siswa adalah kemampuan siswa untuk melakukan kegiatan belajar yang bertumpu pada aktifitas dan tanggung jawab siswa dengan didorong oleh motivasi diri sendiri. Selain itu, 
motivasi juga erat kaitannya dengan atensi siswa, hal ini diperkuat oleh pernyataan Heliza, dkk. (2012) bahwa motivasi yang tinggi dapat menghasilkan minat atau perhatian terhadap pelajaran.

Kurikulum 2013 menekankan pada dimensi pedagogik modern dalam pembelajaran, yaitu menggunakan pendekatan ilmiah. Pendekatan ilmiah (scientific appoach) dalam pembelajaran sebagaimana dimaksud meliputi mengamati, menanya, mencoba, mengolah, menyajikan, menyimpulkan, dan mencipta (Kemendikbud, 2013). Metode yang dipandang sejalan dengan prinsip pendekatan saintifik/ilmiah adalah Problem Based Learning, Project Based Learning, inkuiri, dan Group Investigation. Metode-metode tersebut mengajarkan kepada peserta didik untuk mengenal masalah, merumuskan masalah, mencari solusi, menguji jawaban sementara dengan melakukan penyelidikan (menemukan fakta - fakta melalui penginderaaan), dan menarik simpulan serta menyajikan secara lisan maupun tertulis (Untari, 2013).

Metode Group Investigation (GI) memiliki karakteristik-karakteristik berikut: melibatkan siswa mulai dari proses perencanaan, baik dalam menentukan topik maupun cara untuk mempelajarinya melalui investigasi, menyiapkan laporan akhir serta melakukan presentasi terkait permasalahan yang didiskusikan, sehingga siswa dituntut untuk memiliki kemampuan yang baik dalam bertanggungjawab, berkomunikasi, dan keterbukaan berpikir dalam suatu kelompok (Rusman, 2010). Menurut Hobri dan Susanto (2006) pada metode ini juga terdapat pembagian tugas-tugas menjadi tugas individu yang berbeda. Sehingga metode tersebut dapat melatih kemandirian (misalnya tanggung jawab) siswa.

Metode Power Teaching (PT) memiliki karakteristik-karakteristik dengan penggunaan berbagai intonasi suara, kemudian dalam menjelaskan suatu materi disertai dengan penggunaan gesture (gerakan), terdapat focuser (hand and eyes) dalam proses belajar mengajar, dan terdapat satu langkah dimana siswa saling berpasangan dan salah satu siswa menjadi guru dan salah satu siswa menjadi murid (dilakukan bergantian) (Biffle, 2013). Barakatu (2007) menyatakan bahwa guru yang menyajikan materi dengan isyarat-isyarat yang jelas dan menarik dengan menggunakan hal-hal baru dan mengesankan akan membuat siswa termotivasi untuk menaruh perhatian (atensi) pada guru tersebut. Sehingga metode tersebut diduga dapat menarik perhatian dan meningkatkan konsentrasi siswa pada saat proses belajar mengajar.

Berdasarkan permasalahan di atas, maka perlu dilakukan upaya untuk meningkatkan atensi dan kemandirian siswa dengan melakukan variasi-variasi metode dalam proses belajar mengajar, sehingga penelitian terkait metode group investigation terintegrasi power teaching penting untuk dilakukan. Pemilihan metode tersebut didasarkan pada karakteristikkarakteristik yang dimiliki oleh kedua metode tersebut. Sehingga dengan metode group investigation terintegrasi power teaching diharapkan dapat memperbaiki kedua permasalahan di atas (kemandirian dan atensi siswa).

Rumusan penelitian ini antara lain: (1) bagaimanakah tingkat kemandirian siswa setelah diajar dengan metode Group Investigation terintegrasi Power Teaching?; (2) bagaimanakah tingkat atensi siswa setelah diajar dengan metode Group Investigation terintegrasi Power Teaching?; (3) bagaimanakah hasil belajar kognitif siswa yang diajar dengan metode Group Investigation terintegrasi Power Teaching?; (4) bagaimanakah respon siswa terhadap pembelajaran dengan metode Group Investigation terintegrasi Power Teaching?; (5) bagaimanakah keterlaksanaan Rencana Pembelajaran (RP) dengan metode Group Investigation terintegrasi Power Teaching?; (6) apakah kendala proses pembelajaran dalam metode Group Investigation terintegrasi Power Teaching?

Tujuan penelitian ini antara lain: (1) mendeskripsikan tingkat kemandirian siswa setelah diajar dengan metode Group Investigation terintegrasi Power Teaching; (2) mendeskripsikan tingkat atensi siswa setelah diajar dengan metode Group Investigation terintegrasi Power Teaching; (3) mendeskripsikan hasil belajar kognitif siswa setelah diajar dengan metode Group Investigation terintegrasi Power Teaching; (4) mendeskripsikan respon siswa terhadap penerapan metode Group Investigation terintegrasi Power Teaching; (5) mendeskripsikan keterlaksanaan Rencana Pembelajaran (RP) menggunakan metode Group Investigation terintegrasi Power Teaching; (6) mendeskripsikan kendala-kendala yang terjadi dalam proses pembelajaran menggunakan metode Group Investigation terintegrasi Power Teaching.

Penelitian ini diharapkan memberikan informasi tentang kemandirian dan atensi siswa dalam pembelajaran biologi yang diajarkan dengan metode group investigation terintegrasi power teaching, sehingga jika penelitian ini berhasil, metode pembelajaran tersebut dapat dijadikan metode pembelajaran alternatif untuk diimplementasikan dalam proses belajar mengajar.

\section{METODE}

Penelitian ini termasuk penelitian eksperimental semu (quasi experiment). Pengambilan data dilaksanakan pada semester tahun pelajaran 2013/2014 di MA Al - Ishlah Paciran dengan subyek penelitian adalah siswa MA Al Ishlah Paciran kelas X tahun ajaran 2013/2014 sebanyak 30 siswa putra dan 30 siswa putri dengan pengambilan sampel dilakukan secara acak. 
Desain penelitian menggunakan One Group PretestPostest Design, dengan bentuk desain sebagai berikut (Fraenkel, dkk., 2012):

$\begin{array}{ccc}\mathrm{O}_{1} & \mathrm{X} & \mathrm{O}_{2} \\ \text { Pretest } & \text { Perlakuan } & \text { Postest }\end{array}$

Keterangan:

$\mathrm{O}_{1} \quad$ : Pretest, pemberian pretest untuk mengetahui kemampuan awal siswa

X : Perlakuan, pembelajaran dengan menggunakan metode Group Investigation terintegrasi Power Teaching

$\mathrm{O}_{2} \quad$ : Postest, pemberian postest untuk mengetahui hasil belajar kognitif siswa setelah dilakukan pembelajaran dengan menggunakan metode Group Investigation terintegrasi Power Teaching

Variabel yang diteliti dalam penelitian ini antara lain: kemandirian siswa, atensi siswa, hasil belajar kognitif siswa, respon siswa, keterlaksanaan rencana pembelajaran, dan kendala selama pembelajaran.

Kemandirian dan atensi siswa diukur menggunakan angket dan pengamatan oleh dua orang pengamat dan dinyatakan dalam bentuk persentase, hasil belajar kognitif siswa diukur dengan menggunakan tes tertulis di awal (pretest) dan tes tertulis di akhir (posttest), yang dianalisis secara deskriptif kualitatif menggunakan $\mathrm{N}$-gain. Respon siswa diukur dengan menggnakan angket, yang dinyatakan dalam bentuk persentase. Keterlaksanaan rencana pembelajaran diukur melalui pengamatan oleh dua orang pengamat yang dinyatakan dalam bentuk skor rata - rata. Kendala selama pembelajaran diukur melalui pengamatan oleh dua orang pengamat, dan dianalisis secara deskriptif kualitatif.

\section{HASIL DAN PEMBAHASAN}

Berdasarkan hasil penelitian, diperoleh data terkait tingkat kemandirian, tingkat atensi, hasil belajar kognitif, respon siswa, keterlaksanaan rencana pembelajaran, dan kendala selama pembelajaran.

\section{Tingkat Kemandirian Siswa}

Kemandirian siswa diukur berdasarkan aspek percaya diri dan aspek tanggung jawab. Kemandirian diukur melalui angket dan pengamatan oleh dua orang pengamat. Berikut hasil kemandirian siswa putra dan siswa putri yang diukur menggunakan angket.

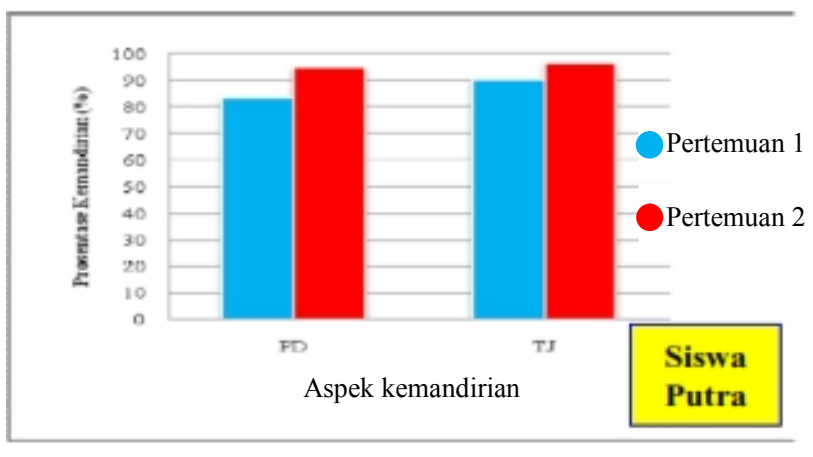

Gambar 1. Tingkat kemandirian siswa MA Al-Ishlah (pengamatan) pada pembelajaran Biologi dengan Group Investigation terintegrasi Power Teaching (kelas putra)

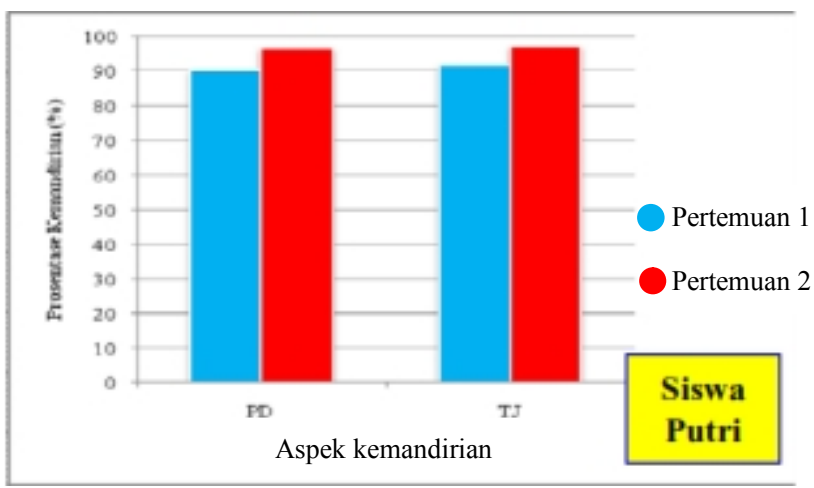

Gambar 2. Tingkat kemandirian siswa MA Al-Ishlah (pengamatan) pada pembelajaran Biologi dengan Group Investigation terintegrasi Power Teaching (kelas putri)

Tingkat kemandirian siswa dapat bertahan dengan baik pada proses pembelajaran pada pertemuan pertama ataupun pertemuan kedua, baik di kelas putra maupun kelas putri, Kemandirian siswa kelas putra untuk aspek percaya diri pada pertemuan pertama memperoleh skor rata-rata kemandirian sebesar $84 \%$ dengan kategori baik sekali, dan $90 \%$ untuk aspek tanggung jawab, sedangkan pertemuan kedua kelas putra diperoleh rata - rata kemandirian sebesar 95\% untuk aspek percaya diri, dan 96.2\% untuk aspek tanggungjawab dengan kategori baik sekali. Skor kemandirian kelas putri pada pertemuan pertama, yaitu 90.4\% untuk aspek percaya diri, dan 91.7\% untuk aspek tanggungjawab dengan kategori baik sekali, sedangkan pada pertemuan kedua memperoleh rata-rata kemandirian sebesar $96.7 \%$ untuk aspek percaya diri dan 97.3\% untuk aspek tanggungjawab, dengan kategori baik sekali. Hal ini dapat dilihat lebih jelas pada gambar 1 dan 2, aspek kemandirian (percaya diri dan tanggung jawab) dapat bertahan dengan baik pada proses pembelajaran di setiap pertemuannya, hal tersebut dapat diasumsikan bahwa kemandirian siswa dapat bertahan dengan baik selama proses pembelajaran setelah diajarkan menggunakan metode pembelajaran Group Investigation terintegrasi Power Teaching. 
Hasil penelitian di atas sesuai dengan penelitian beberapa peneliti, namun pada penelitian yang dilakukan bukan terkait integrasi metode, namun terkait penggunaan metode Group Investigation atau Power Teaching secara terpisah. Sya'roni (2010), dalam penelitiannya menjelaskan bahwa Group Investigation dapat mempertahankan kemandirian siswa. Hal ini dibuktikan oleh hasil penelitian yang diperolehnya. Kemandirian belajar siswa mengalami peningkatan sebesar 5,09\% dari siklus I ke siklus II yaitu dari 70,20\% menjadi 75,29\%. Metode ini juga mempertahankan aspek percaya diri, hal ini sesuai dengan penelitian Anita, dkk., (2013) menggunakan metode Group Investigation untuk mengetahui pengaruhnya terhadap rasa percaya diri. Hasil penelitiannya menunjukkan bahwa penggunaan Group Investigation dapat mempertahankan rasa percaya diri siswa dibanding dengan kelas kontrol (dari 8 indikator rasa percaya diri diperoleh hasil skor untuk kelas Group Investigation meningkat secara tajam kecuali satu indikator saja yang mengalami peningkatan yang sangat kecil). Jika ditinjau dari segi Power Teaching, metode ini juga berkaitan erat dengan kemandirian siswa, karena metode Power Teaching ini berdasarkan pada pembelajaran yang berpusat pada siswa. Hal tersebut sesuai dengan pernyataan Biffle (2013) bahwa pada metode Power Teaching mengajarkan siswa dengan strategi "student centered". Hal ini sesuai dengan prinsip kemandirian yang diungkapkan oleh Rusman (2011) bahwa kemandirian diartikan sebagai bentuk tidak bergantung kepada orang lain, bebas, dan dapat melakukan sendiri. Prinsip berpusat pada siswa adalah mengalihkan fokus dari guru menuju siswa (Silberman, 2006 dalam Santrock, 2009). Muna, dkk. (2012) berpendapat bahwa metode pengajaran berdasarkan pada prinsip kemandirian akan menjadikan siswa menjadi individu yang mandiri. Kemandirian yang dimiliki oleh siswa diwujudkan melalui kemampuannya dalam mengambil keputusan sendiri tanpa pengaruh dari orang lain. Kemandirian juga terlihat dari berkurangnya ketergantungan siswa terhadap guru di sekolah.

Kemandirian siswa juga diukur menggunakan angket, berikut hasil penelitian kemandirian yang didapatkan melalui angket kemandirian.

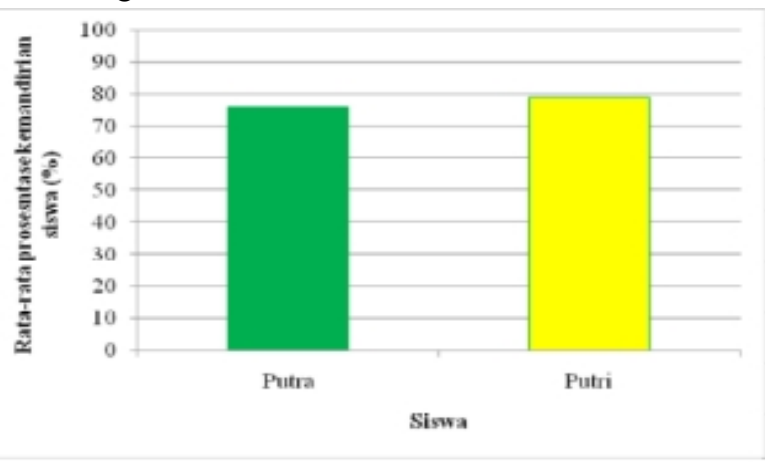

Gambar 3. Tingkat kemandirian siswa MA Al-Ishlah (angket) pada pembelajaran Biologi dengan Group Investigation terintegrasi Power Teaching

Rata-rata hasil angket kemandirian pada gambar 3 (tiga) menunjukkan bahwa siswa putri memiliki tingkat kemandirian yang lebih tinggi dibanding siswa putra, hal tersebut sesuai dengan hasil pengamatan oleh kedua pengamat, yang menunjukkan bahwa kelas putri mendapatkan rata - rata lebih tinggi dibandingkan dengan kelas putra. Perbedaan hasil antara kelas putra dan putri (meskipun tergolong dalam kategori yang sama) tersebut dapat terjadi dikarenakan pada dasarnya tingkat kemandirian siswa juga dipengaruhi oleh berbagai faktor internal ataupun eksternal. Steinberg (2002) dalam Afianti, dkk., (2010) menyatakan faktor - faktor kemandirian meliputi faktor eksternal dan faktor Internal. Faktor eksternal meliputi keluarga, kelompok teman sebaya, sekolah, dan masyarakat. Faktor endogen meliputi faktor fisiologis dan psikologis. Faktor fisiologis di antaranya adalah kondisi fisik seperti sehat dan tidak sehat atau sempurna dan tidak sempurna, sedangkan faktor psikologis meliputi bakat, minat, motivasi, dan kognisi.

\section{Tingkat Atensi Siswa}

Atensi siswa diukur pada aspek atensi ekskutif dan atensi berkelanjutan, dimana pengukuran tersebut diukur menggunakan angket dan juga pengamatan oleh dua orang pengamat.

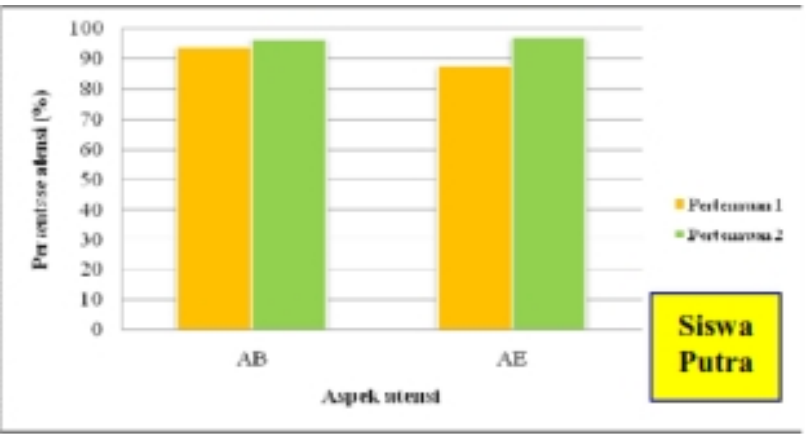

Gambar 4. Tingkat atensi siswa MA Al-Ishlah (pengamatan) pada pembelajaran Biologi dengan Group Investigation terintegrasi Power Teaching (kelas putra)

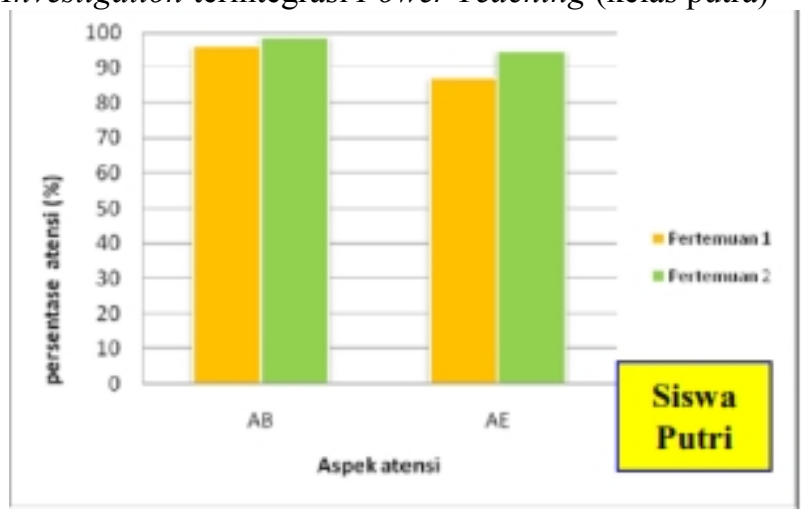


Gambar 5. Tingkat atensi siswa MA Al-Ishlah (pengamatan) pada pembelajaran Biologi dengan Group Investigation terintegrasi Power Teaching (kelas putri)

Tingkat atensi siswa juga dapat bertahan dengan baik pada proses pembelajaran untuk setiap aspeknya, pertemuan pertama untuk kelas putra memperoleh rata rata skor atensi siswa yaitu $93.9 \%$ untuk atensi berkelanjutan, dan $87.6 \%$ untuk atensi ekskutif, dengan kategori baik sekali, sedangkan pada pertemuan kedua kelas putra mendapatkan rata - rata atensi berkisar ansebesar 96.4\% untuk atensi berkelanjutan, dan 97\% untuk atensi ekskutif dengan kategori baik sekali. Tingkat atensi kelas putri pada pertemuan pertama mendapatkan rata - rata atensi sebesar 96.2\% untuk atensi berkelanjutan, dan $87.2 \%$ untuk atensi ekskutif, dengan kategori baik sekali, sedangkan kelas putri pada pertemuan kedua diperoleh rata - rata atensi sebesar 98.8\%\% untuk atensi berkelanjutan dan 94.6\% untuk atensi ekskutif, dengan kategori baik sekali. Gambar 4 dan 5 menunjukkan dengan jelas atensi yang dapat bertahan baik pada pertemuan pertama dan kedua.

Aspek atensi yang dapat dipertahankan di atas dapat terjadi karena adanya integrasi metode antara Goup Investigation dan Power Teaching. Metode Group investigasi memiliki langkah - langkah pembelajaran yang berkaitan erat dengan atensi ekskutif, yaitu terkait pemecahan masalah, hal ini sesuai dengan pernyataan Santrock (2011) bahwa atensi eksekutif melibatkan perencanaan tindakan, mengalokasikan perhatian pada tujuan, deteksi kesalahan dan kompensasi, pemantauan kemajuan pada tugas-tugas, dan berurusan dengan keadaan yang menantang/sulit. Metode Power Teaching juga berkaitan erat dengan atensi siswa, karena di dalamnya terdapat langkah - langkah pembelajaran, yang dapat menarik perhatian siswa, hal ini sesuai dengan pernyataan Teng (2012) bahwa Power Teaching mampu mempertahankan atensi dan konsentrasi siswa. Class Yes adalah salah satu langkah yang sangat berpengaruh dalam memusatkan perhatian siswa, hal ini dikarenakan terdapat variasi - variasi intonasi dalam pelafalannya. Selain itu terdapat focuser dalam metode ini, yaitu Hand and Eyes, siswa meletakkan tangan di atas meja dan fokus terhadap penjelasan guru. Biffle (2013) juga menyatakan bahwa untuk memusatkan perhatian siswa guru berkata "Class!" atau "Class! Class!" atau "Classity Class!" dengan berbagai nada suara dan kemudian siswa merespon dengan kata "Yes!" atau "Yes! Yes!" atau "Yesity Yes!" sesuai dengan intonasi dan nada guru.

Atensi juga dipengaruhi oleh beberapa faktor, baik internal ataupun eksternal. Faktor internal misalnya, motivasi belajar siswa terhadap mata pelajaran yang sedang dipelajari, sedangkan faktor eksternal bisa dikarenakan terpengaruh oleh teman sebayanya yang mengajaknya berbicara atau melakukan aktivitas lain, sehingga hal ini mempengaruhi siswa untuk fokus pada aktivitas yang diminta guru untuk mengerjakan. Felix dalam Sari (2013) menyatakan bahwa faktor internal yang mempengaruhi atensi yaitu karakteristik siswa, seperti usia, motivasi, perilaku, dan lain sebagainya. Sedangkan Sari (2013) menyatakan bahwa faktor eksternal siswa yaitu waktu, frekuensi kontak siswa dengan materi, dan jumlah siswa di kelas akan mempengaruhi tingkat atensi siswa terhadap mata pelajaran yang sedang diajarkan.

Tingkat atensi siswa juga diukur menggunakan angket, yang diisi secara individu oleh siswa, hasil tersebut dapat disajikan dalam gambar 6 .

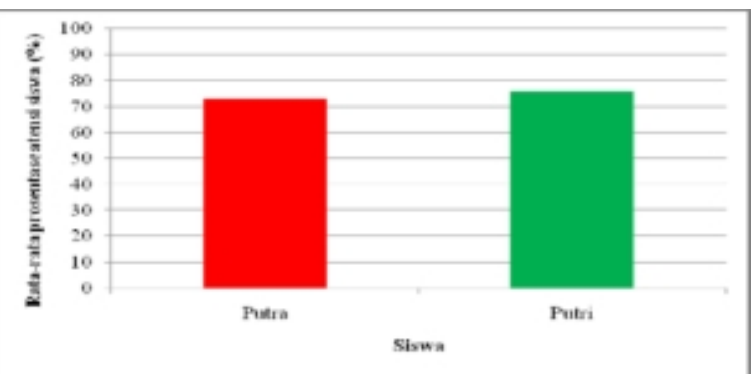

Gambar 6. Tingkat atensi siswa MA Al-Ishlah (angket) pada pembelajaran Biologi dengan menggunakan meted Group Investigation terintegrasi Power Teaching

Hasil angket atensi kelas putra berkisar antara $66 \%$ - 82\%, dengan kategori baik hingga baik sekali. Sedangkan hasil angket dari kelas putri menunjukkan hasil rata - rata skor atensi berkisar antara 68\% - 88\%, dengan kategori baik hingga baik sekali. Siswa putri mendapatkan rata - rata skor atensi lebih tinggi dibandingkan siswa putra, akan tetapi untuk rata - rata klasikal baik kelas putra ataupun kelas putri tergolong dalam kategori atensi baik.

\section{Hasil Belajar Kognitif Siswa}

Hasil belajar siswa ini dibedakan menjadi dua, yaitu pretest dan posttest, hal ini digunakan agar dapat mengetahui peningkatan hasil belajar setiap siswa. Pretest diberikan sebelum perlakuan, sedangkan posttest diberikan setelah perlakuan.

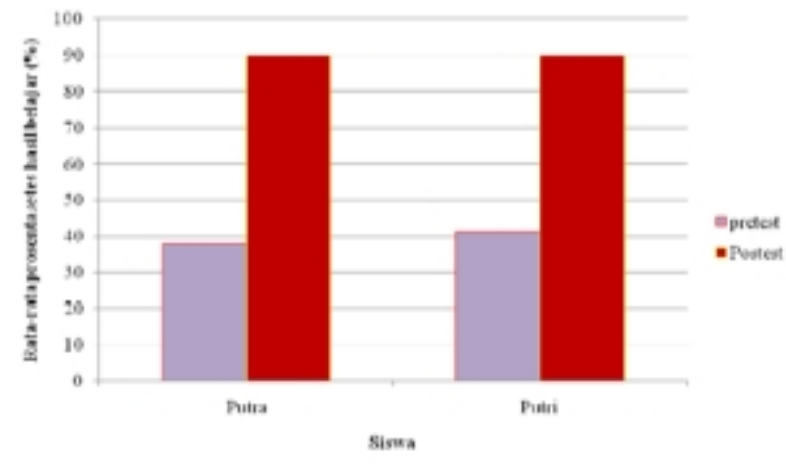

Gambar 7. Rata-rata tes hasil belajar siswa

Ketetapan Kriteria Ketuntasan Minimal (KKM) untuk mata pelajaran Biologi di MA Al-Ishlah Paciran, Lamongan adalah $\geq 0,75$. Sehingga siswa dianggap tuntas jika proporsi hasil belajarnya mencapai 0,75. Hasil pretest pada kelas putra secara klasikal tidak tuntas, 
karena seluruh subjek tidak tuntas (tidak ada siswa yang tuntas) karena hasil jawaban siswa tidak sesuai dengan KKM yang telah ditentukan. Selain itu juga tidak terdapat indikator yang tuntas.

Hasil pretest kelas putri secara klasikal tidak tuntas sebagaimana kelas putra karena proporsi jawaban tidak sesuai dengan KKM yang telah ditentukan, tidak terdapat satupun siswa yang mengalami ketuntasan, selain itu tidak terdapat satu indikatorpun yang tuntas pada saat pemberian pretest.

Hasil posttest kelas putra mengalami peningkatan proporsi jawaban dari subjek, 30 subjek yang diteliti, hanya dua siswa yang tidak tuntas dan 28 subjek lainnya mencapai KKM Biologi. Sehingga secara klasikal kelas yang diajarkan dengan menggunakan metode pembelajaran Group Investigation terintegrasi Power teaching dapat dikatakan tuntas karena melampaui KKM yaitu mencapai rata - rata 0.90 , sedangkan untuk ketuntasan indikator hanya 1 (satu) indikator saja yang tidak tuntas, yaitu indikator nomor 8 (delapan) yaitu hanya sebesar 0.67 (data tidak dipublikasikan), sedangkan secara klasikal indikator yang dicapai yaitu sebesar 0.90, sehingga hal ini dapat dikatakan bahwa pembelajaran menggunakan Group Investigation terintegrasi Power teaching dapat meningkatkan ketuntasan belajar siswa baik ketuntasan individual, indikator, maupun klasikal. Sebagaimana yang dijelaskan di awal, metode Group Investigation terintegrasi Power Teaching mempertahankan kemandirian siswa, sedangkan kemandirian itu sendiri berkaitan erat dengan keberhasilan proses belajar siswa, hal ini sesuai dengan penelitian Wardani dan Noviani (2010) yang menyatakan bahwa kemandirian dapat mempertahankan prestasi belajar siswa. Peserta didik yang mempunyai kemandirian belajar yang tinggi dapat berperilaku inisiatif, eksploratif, kreatif, mampu mengekspresikan diri, berusaha mengatasi masalah, berani bertanggungjawab atas apa yang dikerjakannya, mampu melakukan tugas-tugas yang diberikan pendidik atas kemampuan dan usaha dari dirinya sendiri, berani mengutarakan pendapat dan aktif dalam proses belajar mengajar dan mencari pengalaman belajar.

Hasil posttest kelas putri mengalami peningkatan proporsi jawaban dari subjek, sebagaimana pada kelas putra, 30 subjek yang diteliti, hanya dua siswa yang tidak mencapai KKM, yaitu hanya memperoleh nilai 0.70 (di bawah KKM), sedangkan 28 subjek lainnya tergolong dalam kategori tuntas karena mencapai KKM Biologi. Sehingga secara klasikal kelas yang diajarkan dengan menggunakan metode pembelajaran Group Investigation terintegrasi Power teaching dapat dikatakan tuntas karena melampaui KKM yaitu mencapai rata - rata 0.90. Kelas putri memiliki kemandirian dan atensi yang tinggi pada saat proses pembelajaran, sebagaimana penjelasan di awal, bahwa atensi dapat dapat bertahan baik selama proses pembelajaran karena penggunaan metode pembelajaran Group Investigation terintegrasi Power teaching. Atensi yang bertahan dengan baik ini berkaitan erat dengan hasil belajar, hal ini sesuai dengan pernyataan Tang \& Posner dalam Santrock (2011) bahwa peningkatan atensi, khususnya atensi ekskutif sangat penting dalam berhasilnya suatu tugas - tugas akademik yang kompleks. Hal ini berkaitan erat dengan pemecahan masalah. Siswa yang memiliki kemampuan dalam menyelesaikan masalah akan memiliki hasil belajar yang baik. Hal tersebut juga didukung oleh penelitian Mochtar (2013) bahwa penggunaan pendekatan pemecahan masalah dapat mempertahankan hasil belajar siswa, yaitu dari 68,33 (pada siklus I) menjadi 76,66 (pada siklus II). Pemecahan masalah akan berjalan dengan baik jika terdapat perencanaan pemecahan masalah, kemudian siswa diarahkan dalam mengidentifikasi strategi-strategi pemecahan masalah yang sesuai untuk permasalahan yang sedang diselesaikan (Mochtar, 2013).

Ketuntasan indikator pada kelas putri, sebagaimana kelas putra, hanya 1 (satu) indikator saja yang tidak tuntas, yaitu indikator nomor 8 (delapan) (data tidak dipublikasikan), namun secara klasikal indikator yang dicapai sebesar 0.90. Sehingga baik pada kelas putra ataupun kelas putri dapat dikatakan bahwa pembelajaran menggunakan Group Investigation terintegrasi Power teaching dapat meningkatkan ketuntasan belajar siswa baik ketuntasan individual, indikator, maupun klasikal.

Hasil belajar kognitif siswa diberikan sebelum perlakuan dan sesudah perlakuan, sehingga dapat diketahui peningkatan hasil belajar kognitifnya. Hasil tersebut menunjukkan pada kelas putra mengalami peningkatan penguasaan konsep yang ditunjukkan oleh nilai gain dengan kategori sedang (hanya lima siswa) hingga gain tinggi, yaitu $\geq 0.7$, nilai gain tersebut berkisar antara 0.6 sampai 1.0, sedangkan tabel 4.9 menunjukkan peningkatan yang terjadi pada kelas putri, nilai gain pada kelas putri juga berkisar antara 0.6 sampai 1.0, yaitu terdapat empat siswa yang tergolong dalam kategori gain sedang dan 26 siswa lainnya tergolong dalam gain tinggi. Hal ini berarti bahwa kemampuan penguasaan konsep yang diberikan baik pada kelas putra ataupun kelas putri melalui pembelajaran dengan menggunakan Group Investigation terintegrasi Power Teaching secara klasikal tinggi. Selain untuk mengetahu penguasaan konsep, N-Gain juga bertujuan untuk mengetahui perbedaan antara sesudah dan sebelum dilakukan perlakuan (data tidak dipublikasikan).

\section{Angket Respon Siswa}

Respon siswa diukur menggunakan angket, pada angket tersebut terdapat 13 aspek yang diukur (data tidak dipublikasikan). Berdasarkan hasil angket respon siswa ini, menunjukkan bahwa dengan menggunakan metode pembelajaran Group Investigation terintegrasi Power Teaching dapat menumbuhkan minat dan rasa ingin tahu siswa. Minat dan rasa ingin tahu siswa, masing-masing untuk kelas putra adalah sebesar $74 \%$ dan $90 \%$, sedangkan untuk kelas putri, masing - masing sebesar $93 \%$.

Siswa yang menyatakan bahwa dengan metode pembelajaran yang diberikan, dapat menjadikan pelajaran tersebut menarik dan tidak membosankan. Kelas putra mendapatkan skor sebesar $76 \%$ dan untuk kelas putri 
adalah sebesar 90\%. Siswa juga mengakui bahwa dengan pembelajaran biologi seperti ini dapat membuat siswa senang dan tertarik terhadap pembelajaran biologi yaitu sebesar $73 \%$ untuk kelas putra dan $90 \%$ untuk kelas putri. Pembelajaran biologi seperti ini juga menjadikan mereka semangat untuk menyimak materi, yaitu sebesar $73 \%$ untuk kelas putra dan $97 \%$ untuk kelas putri. Hal ini sesuai dengan pernyataan Jaeggi, dkk., (2009) dan Tang \& Posner (2009) dalam Santrock (2011), bahwa metode pembelajaran harus dibuat menarik, karena kebosanan dapat mengganggu siswa, jika siswa bosan, maka perhatiannya akan berkurang. Barakatu (2007) juga menyatakan bahwa guru dapat menarik perhatian siswa jika menyajikan materi dengan isyarat-isyarat yang jelas dan menarik dengan menggunakan hal-hal baru dan mengesankan, dengan hal tersebut akan membuat siswa termotivasi untuk menaruh perhatian (atensi) pada guru.

Angket tersebut juga menunjukkan bahwa siswa senang dengan metode pembelajaran seperti ini dikarenakan dapat berdiskusi dengan baik bersama teman ataupun guru, skor yang diperoleh yaitu sebesar $83 \%$ untuk kelas putra dan $97 \%$ untuk kelas putri. Siswa juga menyatakan bahwa siswa tidak tertekan dan tegang selama pembelajaran, yaitu sebesar $87 \%$ untuk kelas putra dan 97\% untuk kelas putri. Metode seperti ini juga membuat siswa mudah memahami materi dan lebih termotivasi dalam belajar, skor masing - masingnya sebesar $90 \%$ dan $83 \%$ untuk kelas putra, sedangkan untuk kelas putri, masing - masing $80 \%$ dan $74 \%$.

Siswa menyatakan bahwa kegiatan dalam LKS yang diberikan memperjelas pemecahan masalah, yaitu sebesar 73\% dari kelas putra dan 90\% dari kelas putri. LKS yang diberikan juga memberikan kebebasan siswa dalam mengemukakan ide yaitu sebesar 70\% untuk kelas putra dan $84 \%$ untuk kelas putri. $80 \%$ siswa putra dan $90 \%$ siswa putri menyatakan bahwa pertanyaan pada LKS singkat dan jelas serta mudah dipahami.

Buku ajar yang diberikan oleh peneliti juga mendapat respon baik dari siswa, 93\% dari kelas putra dan $87 \%$ dari kelas putri menyatakan bahwa pada buku tersebut terdapat aktivitas yang dapat melatih kemandirian siswa. Siswa juga menyatakan bahwa pada buku yang diberikan terdapat aktivitas permainan yang dapat memusatkan perhatian siswa, yaitu sebesar $80 \%$ untuk kelas putra dan 100\% untuk kelas putri. Siswa juga menyatakan bahwa buku tersebut memiliki desain yang bagus, sehingga menarik perhatian siswa untuk membacanya, yaitu sebesar $83 \%$ untuk kelas putra dan 96\% untuk kelas putri.

Skor respon siswa tersebut menunjukkan bahwa perangkat pembelajaran dan kegiatan pembelajaran dengan metode Group Investigation terintegrasi Power Teaching mampu mempertahankan kemandirian dan atensi siswa dalam proses pembelajaran.

\section{Keterlaksanaan Rencana Pembelajaran}

Hasil pengamatan keterlaksanaan RPP mendapat rata-rata skor keterlaksanaan berdasarkan kegiatan pembuka, inti dan penutup selama dua kali tatap muka dapat terlaksana dengan baik.

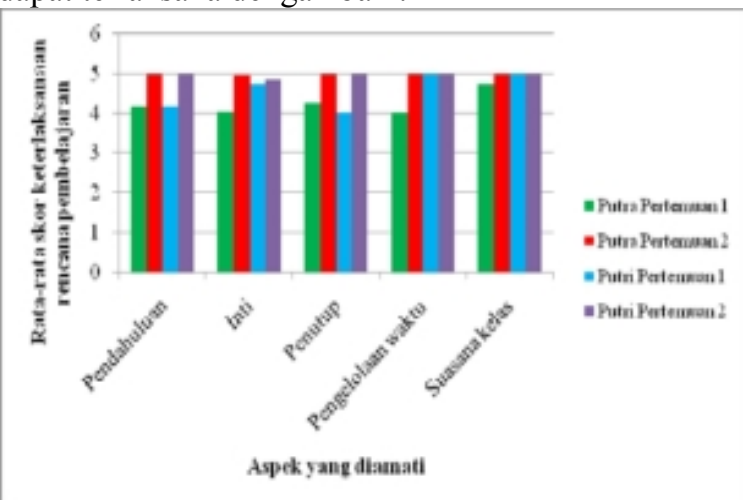

Gambar 8. Hasil Keterlaksanaan Rencana Pembelajaran

Keterlaksanaan pembelajaran terdiri dari lima aspek yang diamati, yaitu 1) kegiatan pendahuluan, yang terdiri dari kegiatan memotivasi siswa, mengingatkan dengan pembelajaran terdahulu, dan menjelaskan tujuan pembelajaran; 2) kegiatan inti yang meliputi presentasi materi, mengorganisasikan siswa untuk belajar, membimbing siswa dalam investigasi dan pengamatan, mengembangkan dan mempresentasikan hasil investigasi, dan menganalisis dan mengevaluasi pembedahan; 3) kegiatan penutup, meliputi: memberikan rangkuman pembelajaran dan memberikan tugas. Aspek ke-4 dan ke5 adalah pengelolaan waktu dan pengamatan suasana kelas.

Berdasarkan hasil pengamatan keterlaksanaan pembelajaran yang dilakukan oleh dua pengamat menunjukkan seluruh tahapan terlaksana secara keseluruhan baik pada kelas putra ataupun kelas putri dengan kategori tiap aspek adalah sangat baik yaitu rentang antara 4.25 - 5 untuk kelas putra dan juga $4.25-$ 5 untuk kelas putri.

Selama kegiatan pembelajaran, guru hanya bertindak sebgai fasilitator dan mendampingi siswa dalam menyelesaikan permasalahan yang ada melalui lembar kegiatan siswa yang diberikan. Hal ini dimaksudkan agar siswa mampu dan terbiasa memecahkan masalah secara mandiri yang dilakukan dalam kelompok. Dalam hal ini peneliti tetap melakukan bimbingan dan tidak langsung memberikan jawaban, melainkan hanya memberi arahan dan bimbingan siswa untuk memecahkan masalah melalui kegiatan investigasi kelompok berdasarkan LKS yang dikembangkan oleh peneliti.

Kedua pengamat mengatakan bahwa siswa sangat antusias pada saat pembelajaran, hal ini dikarenakan para siswa belum pernah mendapatkan metode pembelajaran yang digunakan, dan mendapatkan guru baru, sehingga terdapat suasana baru pada kelas tersebut, namun terdapat saran dari pengamat bahwa pada saat menjelaskan konsep umum, guru terlalu cepat. Hal ini dikarenakan waktu yang kurang memungkinkan, karena terkadang pada pertemuan di hari tertentu hanya dengan waktu 45 menit saja, sedangkan terdapat kelas lain (kelas putri) yang mana pada pertemuan tersebut dilangsungkan 2x45 menit, sehingga akan terkesan lebih santai dalam melakukan kegiatan pembelajaran. 
Rata - rata reliabilitas instrumen keterlaksanaan RPP sebesar $89.48 \%$ untuk kelas putra dan $92.11 \%$ untuk kelas putri. Dalam hal ini bisa diasumsikan bahwa instrumen yang digunakan masih reliabel. Intrumen keterlaksanaan RPP dikatakan reliabel, apabila releabilitasnya $\geq 75 \%$ (Borich, 1994 dalam Ibrahim, 2005 dalam Wulandari, 2011). Hal ini menunjukkan bahwa intrumen keterlaksanaan RPP yang telah dibuat memiliki konsistensi atau keajegan dalam mengukur keterlaksanaan RPP selama pembelajaran.

\section{Kendala Selama Pembelajaran}

Kendala pada proses pembelajaran, diamati oleh dua orang pengamat berdasarkan lembar pengamatan yang telah disediakan.

Tabel 1. Kendala Selama Proses Pembelajaran

\begin{tabular}{|c|c|}
\hline Kendala & Solusi \\
\hline $\begin{array}{lr}\text { Kurang } & \text { maksimalnya } \\
\text { pembuatan media 3D } \\
\text { karena } & \text { kurang } \\
\text { tersedianya alat dan } \\
\text { bahan, mengingat siswa } \\
\text { tinggal di area pondok } \\
\text { (tinggal di asrama, dan } \\
\text { sulit untuk mendapatkan } \\
\text { ijin keluar) }\end{array}$ & $\begin{array}{l}\text { Pembuatan media bisa } \\
\text { menggunakan barang } \\
\text { seadanya yang terdapat di } \\
\text { pondok }\end{array}$ \\
\hline
\end{tabular}

Kendala yang dihadapi tidak banyak terjadi, kendala pada penelitian ini adalah kurang sesuainya pembuatan media dengan rencana awal, yaitu pembuatan media 3D (3 Dimensi) kurang maksimal (Tabel 1), hal ini dikarenakan kurang tersedianya alat dan bahan, mengingat siswa tinggal di area pondok (tinggal di asrama), sehingga untuk melakukan perijinan keluar sangatlah sulit. Sehingga solusi yang dapat diberikan yaitu pembuatan media tersebut dapat menggunakan barang yang tersedia di area pondok, sehingga hal ini akan lebih melatih kreativitas siswa.

\section{PENUTUP}

\section{Simpulan}

Bedasarkan hasil penelitian ini, maka dapat disimpulkan bahwa metode pembelajaran Group Investigation terintegrasi Power Teaching dapat mempertahankan kemandirian, atensi, dan hasil belajar kognitif siswa MA Al-Ishlah kelas X, Paciran- Lamongan pada materi ekosistem. Penggunaan metode tersebut juga mendapatkan respon yang baik, dan keterlaksanaan rencana pembelajaran yang juga tergolong baik sekali, serta kendala pembelajaran yang bisa diselesaikan dengan kreativitas siswa.

\section{Saran}

Metode pembelajaran Group Investigation terintegrasi Power Teaching dapat digunakan sebagai alternatif untuk mempertahankan kemandirian dan atensi siswa, namun yang perlu diperhatikan juga dalam pemilihan materi dan pembimbingan.

\section{DAFTAR PUSTAKA}

Afianti, R., Hartati, S., \& Sawitri., D. R. (2010). Hubungan Antara Self Regulated Learning (SLR) Dengan Kemandirian Pada Siswa Program Akselerasi SMA Negeri 1 Purworejo. e-Journal UNDIP, 1-19.

Anita, N. M., Karyasa, I. W., \& Tika, I. N. (2013). Pengaruh Model Pembelajaran Kooperatif Tipe Group Investigation (GI) Terhadap Self-Efficacy Siswa. e-Journal Program Pascasarjana Universitas Pendidikan Ganesha, 1-10.

Barakatu, R. A. (2007). Membangun Motivasi Berprestasi: Pengembangan Selff-Efficacy dan Penerapannya Dalam Dunia Pendidikan. Lentera Pendidikan, 37-51.

Biffle, C. (2013). Whole Brain Teaching For Challenging Kids (And The Rest Of Your Class, Too!). McGrawHill: New York.

Ekamayanti. (2012). Penggunaan Metode Examples and Examples untuk Meningkatkan Minat Belajar IPS Pada Siswa Kelas IX SMPN 7 Pinggir Kabupaten Bengkalis. Riau: Universitas Riau.

Gani, A. R. (2008). The Effect of Formative Test and Learning Autonomy on the SMA Learners Achiefment In Economics. Jurnal Penelitian dan Evaluasi Pendidikan, 162-176.

Haryono, M. (2007). Penggunaan Variasi Metode Mengajar untuk Membangkitkan Motivasi Belajar Matematika. Widyatama, 11-21.

Kurniawan, R. (2012). Hubungan antara Minat Membaca dengan Kemandirian Belajar Siswa Kelas X Jurusan Teknik Kendaraan Ringan SMK Piri 1 Yogyakarta Tahun Ajaran 2012/2013. Yogyakarta: Universitas Negeri Yogyakarta.

Kurniawati, D. (2010). Upaya Meningkatkan Kemandirian Belajar Siswa Dalam Pembelajaran Matematika Melalui Model Cooperative Learning Tipe Kepala Bernomor Terstruktur Pada Siswa SMP N 2 Sewon Bantul. Yogyakarta: Universitas Negeri Yogyakarta.

Maria, H. T. (2010). Implementasi Pembelajaran Multimodel Berbasis Pendekatan Kontekstual untuk Meningkatkan Pencapaian Kompetensi Dasar Fisika di SLTP. Jurnal Pendidikan Matematika Dan IPA , $35-43$.

Muna, N. F., Sri, H., \& Imam, S. (2012). Hubungan Antara Kemandirian Dengan Motif Berkompetisi Pada Siswa Kelas VII Rintisan Sekolah Bertaraf Internasional. Semarang: Universitas Diponegoro

Riyanto, B. (2012). Pengaruh Motivasi Belajar Terhadap Keterampilan. e-Journal Pendidikan Teknik Mesin Otomotif IKIP Veteran Semarang, 1-10. 
Rusman. (2011). Model-Model Pembelajaran Mengembangkan Profesionalisme Guru. Jakarta: PT RajaGrafindo Persada.

Santrock, W. J. (2011). Educational Psychology. New York: McGraw-Hill Companies, Inc.

Sari, S. R. (2013). The Correlation Between Internal \& External Factors that Influence Elementary School Students In Learning English Vocabulary And Their Grade In Vocabulary Test: A study On The Thihrd Graders Of Marsudiri 77 Elementary School Salatiga. FLLT Conference (pp. 578-588). Thailand: Language Institute Of Thammasat University.

Setiawan, G. D., Sedanayasa, G. S., \& Suranata, K. S. (2013). Penerapan Konseling Behavioral dengan Strategi Self Management untuk Meningkatkan Kemandirian dalam Mengambil Keputusan Siswa X5 SMA Negeri 2 Singaraja Tahun Pelajaran 2012/2013. Jurnal Ilmiah Bimbingan Dan Konseling , 1-10.

Sternberg, J. R. (2003). Cognitive Psychology, Third Edition. USA: Thomson Learning, Inc.

Sunarsih, T. (2009). Hubungan Antara Motivasi Belajar, Kemandirian Belajar Dan Bimbingan Akademik Terhadap Prestasi Belajar Mahasiswa Di Stikes A. Yani Yogyakarta. Surakarta: Universitas Sebelas Maret.

Suwatik. (2010). Penerapan Metode Numbered Heads Together (Nht) Untuk Meningkatkan Minat dan Hasil Belajar Geografi pada Kompetensi Dasar Menganalisis Hidrosfer dan Dampaknya terhadap Kehidupan di Muka Bumi Siswa Kelas X-2 SMA Negeri 6 Surakarta Tahun 2009/2010. Surakarta: Universitas Sebelas Maret.
Sya'roni, M. (2010). Penggunaan Pendekatan Group Investigation Sebagai Upaya Meningkatkan Kemandirian Dan Prestasi Belajar Siswa Pada Pembelajaran Matematika Di SMPN 1 Seyegan. Yogyakarta: Lumbung Pustaka Universitas Negeri Yogyakarta.

Syukur, A. (2013). Penggunaan Video dalam Pembelajaran Materi Metabolisme untuk Mengungkap Keterampilan Mengajukan Pertanyaan dan Meningkatkan Keterampilan Berpikir Kritis Siswa SMA Kelas XII IPA. Retrieved Desember 28, 2013, from Perpustakaan.upi.edu: http://repository.upi.edu/3465/

Teng, L. M. (2012). Pembelajaran Aktif Melalui Whole Brain Teaching Bagi Menarik Dan Mengekalkan Perhatian Pelajar Dalam Subjek Sains Tingkatan Tiga. Retrieved Januari 9, 2014, from Academia.edu:

http://s3.amazonaws.com/academia.edu.documents/ 32360711/

Uno, H. B. (2011). Teori Motivasi dan Pengukurannya. Jakarta: Penerbit Bumi Aksara.

Untari, M. F. (2013). Implementasi Pendekatan Saintifik (Scientific Approach) dalam Pembelajaran di Sekolah Dasar. Implementasi Pembelajaran Tematik dalam Pengoptimalan Kurikulum 2013 (pp. 1-6). Semarang: IKIP PGRI Semarang.

Wardani, D. K., \& Noviani, L. (2010). Model Jigsaw Dalam Perkuliahan Pengantar Ilmu Ekonomi Untuk Meningkatkan Kemandirian Dan Prestasi Mahasiswa. Paedagogia Jurnal Penelitian Pendidikan, 46-54. 